\title{
Light spectrum on the quality of fruits of physalis species in subtropical area
}

\author{
Daniel Fernandes da Silva¹, Rafael Pio ${ }^{2 *}$, Joyce Dória Rodrigues Soares², Heloisa Helena de Siqueira \\ Elias $^{2}$, Fabiola Villa ${ }^{3}$, Eduardo Valério de Barros Vilas Boas ${ }^{2}$ \\ 1. Universidade Federal de Lavras - Departamento de Biologia - Lavras (MG), Brazil. \\ 2. Universidade Federal de Lavras - Departamento de Agricultura - Lavras (MG), Brazil. \\ 3. Universidade Estadual do Oeste do Paraná - Departamento de Agronomia - Marechal Cândido Rondon (PR), Brazil.
}

\begin{abstract}
The aim of this study was to analyze the effect of colored-shade nets on the physicochemical characteristics of physalis in subtropical area. The experimental design was the randomized blocks with a $4 \times 5$ factorial, being four species of physalis (Physalis peruviana, P. pubescens, P. minima and P. ixocarpa) and four net colors (white, blue, red and black), besides the control under full sun. Titratable acidity (TA), $\mathrm{pH}$, vitamin C, soluble solids (SS), SS/TA relation, total phenolics, anthocyanins and antioxidant capacity were evaluated. It was
\end{abstract}

observed that $P$. peruviana and $P$. pubescens have more acid fruits, and $P$. minima shows vitamin $C$ content higher than the other species. In general, fruits of $P$. peruviana and $P$. pubescens have better quality when grown in white, blue or black shade net; fruits of $P$. minima are physicochemically superior when produced under full sun or under white or blue shade net; finally, fruits of $P$. ixocarpa have low quality when produced under black net.

Key words: Physalis L., postharvest quality, bioactive compounds, antioxidant activity.

\section{INTRODUCTION}

The group of small fruits is well known for having species with high content of bioactive compounds. Among the main fruits belonging to this group, there are blackberry, raspberry, blueberry and strawberry, known for their high content of phenolic compounds, flavonoids and anthocyanins (Souza et al. 2014).

In recent years, physalis has been incorporated to the group, a fruit still considered exotic in South America and with a small cultivation area in Brazil. However, it presents various compounds with nutritional and pharmacological interest. Besides the low acidity, the considerable $\beta$-carotene content and the high content of soluble solids, physalis also contains flavonoids, carotenoids, alkaloids and terpenes with health benefits (Licodiedoff et al. 2013).

Physalis peruviana $\mathrm{L}$. is the most commercially disseminated species; however, there are other equally rich species, such as $P$. pubescens L. and P. minima L., which are also part of the group of species belonging to the genus. In some cases, these species are important agricultural products produced in some countries, such as $P$. ixocarpa $\mathrm{L}$. in Mexico. In Brazil, there is little information on the crop, being necessary researches in order to clarify the cultivation conditions for the production of high-quality physalis fruits.

The fruit quality characteristics are influenced by factors such as edaphoclimatic conditions, variety, period and location of harvest, crop treatment and postharvest handling. Among these, the amount, duration and intensity of light to which the fruits are exposed have a great influence on the final quality of the product (Senhor et al. 2009).

The application of techniques which allow the manipulation of the light spectrum that focuses on plants has brought considerable gains to several agricultural sectors, among which are floriculture, olericulture and, more recently, fruit cultivation. The colored-shade nets, or simply shade cloths, are an alternative that enables improvements in the physicochemical quality of fruits, because of their capacity 
to combine physical protection with a different filtration from solar radiation (Costa et al. 2011).

Amarante et al. (2007) present the importance of coloration for the usage of colored-shade nets in shading regarding fruit cultivation. According to them, nets of different colors presented different behaviors on a number of variables analyzed for the cultivation of the strawberry plant and the apple tree, being positive and negative in response to color and crop.

Based on this argument, the aim of this work was to analyze the alterations in the light spectrum on the quality of fruits of physalis species in subtropical area.

\section{MATERIAL AND METHODS}

The experiment was set in a subtropical area between August 2013 and March 2014. The geographic coordinates of the cultivation location are lat $21^{\circ} 14^{\prime}$ 's; long $45^{\circ} \mathrm{W}$ and $918 \mathrm{~m}$ of altitude. The local climate is of the Cwb type.

The shading structure over the plants was formed by Cromatinet ${ }^{\circ}$ colored-shade nets, Polysack brand, with $50 \%$ shading, in different colorations: white, blue, red and black, attached to a wooden removable structure with $3.0 \times 3.0 \times 1.5 \mathrm{~m}$ in width, length and height, respectively, besides a witness treatment in which the plants grew under full sun.

Seeds of four physalis species were used: P. peruviana, P. pubescens, P. minima and P. ixocarpa. The seeds were extracted from ripe fruits, dried in the shade and, next, sown in polypropylene trays of 128 cells, using a seed per cell with commercial substrate. At 60 days, when they reached ideal transplanting conditions, the seedings of four physalis species were transplanted into 6-L vases in order to continue their development until the productive stage. The substrate used in this stage was a mixture of soil (clayey distroferric Red Latosol, typical of the region) + cattle manure at a 7:3 v/v ratio, enriched with NPK 4-14-8, according to a previous analysis of the soil.

The experimental design was the randomized blocks with a $4 \times 5$ factorial treatment, being four physalis species and four colors of colored-shade nets, besides the witness treatment under full sun. Each treatment was composed of three replicates with two plants per plot.

When entering in production, the plants had their fruits manually harvested, once a week, and then were sent to the Laboratory of Chemistry, Biochemistry and Food Analysis, where the titratable acidity (TA) was analyzed by titration with $\mathrm{NaOH}$, as well as the $\mathrm{pH}$, with a benchtop phmeter, and the soluble solids content (SS), with a digital refractometer. The results of TA and SS were expressed in percentage of citric acid and brix degrees ( ${ }^{\circ}$ Brix), respectively. Next, the ratio SS/TA was calculated. A second extract was prepared for determination of vitamin C (mg of ascorbic acid. $100 \mathrm{~g}^{-1}$ of fresh mass).

The evaluation of bioactive compounds, such as monomeric anthocyanin and total phenolic, was performed according to differential $\mathrm{pH}$ methodology. The results found in these two evaluations were expressed in mg gallic acid equivalent (EAG) $100 \mathrm{~g}^{-1}$ and $\mathrm{mg} \cdot 100 \mathrm{~g}^{-1}$ of pulp. Lastly, it was analyzed the antioxidant capacity by the capture of free-radical DPPH method, expressed in percentage of antioxidant activity.

The variables were analyzed through the grouping of averages by the Scott-Knott test, at 5\% probability, utilizing the statistical program Sisvar.

\section{RESULTS AND DISCUSSION}

There was no significant interaction between the quality of the light provided by the colored-shade nets and the species for TA, with a significant difference only among species (Table 1).

Table 1. Titratable acidity, $\mathrm{pH}$ and vitamin $\mathrm{C}$ (mg of ascorbic acid $100 \mathrm{~g}^{-1}$ of fruit) in fruits of four physalis species in subtropical area.

\begin{tabular}{cccc}
\hline Species & TA & pH & Vitamin C \\
\hline P. peruviana & $1.76 \mathrm{a}$ & $4.06 \mathrm{~b}$ & $31.51 \mathrm{~b}$ \\
\hline P. pubescens & $1.43 \mathrm{a}$ & $4.14 \mathrm{~b}$ & $31.17 \mathrm{~b}$ \\
\hline P. minima & $0.85 \mathrm{~b}$ & $4.23 \mathrm{a}$ & $61.77 \mathrm{a}$ \\
\hline P. ixocarpa & $0.73 \mathrm{~b}$ & $4.37 \mathrm{a}$ & $26.55 \mathrm{~b}$ \\
\hline CV (\%) & $\mathbf{1 0 . 6 5}$ & $\mathbf{5 . 9 7}$ & $\mathbf{2 1 . 9 5}$ \\
\hline
\end{tabular}

Averages followed by the same letter in the column do not differ from one another by the Scott-Knott test at a $5 \%$ probability. TA = Titratable acidity; $\mathrm{CV}=$ Coefficient of variation. 
P. peruviana and P. pubescens are the species which have shown more acidity. Lima et al. (2013) found inferior acidity values for $P$. peruviana during the harvest $(0.89 \%)$. Even lower values were found by Lima et al. (2012), varying between 0.62 and $0.78 \%$ of citric acid.

Unlike P. peruviana and P. pubescens, the results found for the acidity of $P$. ixocarpa were inferior to the ones found in literature, of the order of $0.73 \%$ of citric acid against $1.20 \%$ (Cruz-Álvarez et al. 2012). P. minima, for its virtual absence in plantations with fruit production purpose, being more used as a medicinal plant, presents few data in literature. The only register found for this species reports TA of the fruits of $0.51 \%$ of citric acid (Patel et al. 2011), therefore, fruits more acid than the ones in the present research.

$P$. peruviana and $P$. pubescens are species presenting fruits with more acid $\mathrm{pH}$ (4.06 and 4.14, in this order) when compared to $P$. minima and $P$. ixocarpa, although all the species presented $\mathrm{pH}$ values above 4 , a factor which indicates low acidity in the fruits (Table 1).

The $\mathrm{pH}$ values found in the present study indicate less acid fruits, when compared to the values reported in literature by Silva et al. (2013) and Lima et al. (2013).

The $\mathrm{pH}$ values found for $P$. ixocarpa are in accordance with the values reported by González-Mendoza et al. (2011), who verified variation between 4.10 and 4.56 in different tomatillo genotypes, although higher than the values of nine populations of $P$. ixocarpa studied by Ramírez-Godina et al. (2013) also in Mexico, the main producer of this species.

P. minima was the only species to present a more acid $\mathrm{pH}$ in this study, when compared to literature. Although the data for the species are scarce, Patel et al. (2011) obtained pH of 4.94 in ripe fruits in the physicochemical characterization of P. minima in different development stages of the fruit, whereas in this study the average $\mathrm{pH}$ of the ripe fruits was 4.23.

Regarding the vitamin C (ascorbic acid) content, P. minima stood out for presenting a higher ascorbic acid content in its fruits $\left(61.77 \mathrm{mg} \cdot 100 \mathrm{~g}^{-1}\right)$, being almost two times higher when compared to the other species.

Studies described Physalis species as fruits with considerable vitamin C content (Puente et al. 2011; Patel et al. 2011; Silva et al. 2013); however, in all these works, the values found were inferior to the ascorbic acid content of the fruits cultivated in subtropical area.

Also in complete accordance with the present study, where P. minima and P. ixocarpa were, respectively, the species with higher and lower vitamin $\mathrm{C}$ content, specialized works of
Cruz-Álvarez et al. (2012) with P. ixocarpa demonstrated the low content of vitamin C $\left(8.21\right.$ and $\left.2.61 \mathrm{mg} \cdot 100 \mathrm{~g}^{-1}\right)$, and Patel et al. (2011) found high content in P. minima (46.67 mg. $100 \mathrm{~g}^{-1}$ ).

The vitamin $C$ values presented by the studied physalis species were superior to the ones of other small fruits traditionally known for having this vitamin, such as blackberries and red raspberries (Guedes et al. 2013; Maro et al. 2013), which makes physalis nutritionally appealing.

Fruits of $P$. peruviana under red net presented low values of soluble solids $\left(7.33^{\circ} \mathrm{Brix}\right)$, like the results found for P. pubescens in white net $\left(8.33^{\circ} \mathrm{Brix}\right)$, as well as in full sun. P. minima stands out for presenting a high SS content in all treatments, regarding the analyzed species. P. pubescens also presented a high content of SS. P. minima produced under the subtropical edaphoclimatic conditions presented SS values varying from 9.50 to $10.95^{\circ} \mathrm{Brix}$, much higher than the $4.16^{\circ}$ Brix reported by Patel et al. (2011), representing more than double.

Variable inter and intraspecific SS contents are reported in fruits of the Physalis genus. Silva et al. (2013) and Lima et al. (2013) found 11.26 and $14^{\circ}$ Brix in fruits of P. peruviana cultivated in Maria da Fé, Minas Gerais, and Capão do Leão, Rio Grande do Sul, Brazil, respectively — both values higher than in fruits produced under nets of every coloration and under the edaphoclimatic conditions of Lavras, Minas Gerais, Brazil. For P. ixocarpa, the SS values reported in literature vary from 5.24 to $9.03{ }^{\circ} \mathrm{Brix}$ (Cruz-Álvarez et al. 2012; González-Mendoza et al. 2011), which are similar to the values found in this research.

P. minima presented superior values of ratio for all light spectrum, except under black net. On the other hand, $P$. pubescens and $P$. ixocarpa presented better performance when produced under black net (Table 2). Thus, fruits with a high SS/TA relation represent sweeter fruits, being indicated for in natura consumption, whereas fruits with a low SS/TA relation, because they are more acid, can be indicated for industrialization (Campagnolo and Pio 2012).

P. ixocarpa presented higher anthocyanin content when cultivated under full sun and red net (Table 2). The results found can be explained by the relation between the red and far-red wavelengths, which are directly related to the synthesis of anthocyanin. According to Awad et al. (2001), values of this relation lower than 1 reduce the cyanidin-3-galactoside (anthocyanin), quercetin 3-glucoside and total flavonoid contents, which results in deficient 
Table 2. Soluble solids content ( ${ }^{\circ}$ Brix), ratio (relation soluble solids/titratable acidity), monomeric anthocyanin content (mg pelar-3-gluc-100 g ${ }^{-1}$ ) and antioxidant activity (DPPH, \%) of four physalis species in subtropical area, cultivated under colored-shade nets with different colors.

\begin{tabular}{|c|c|c|c|c|}
\hline \multirow{2}{*}{ Net coloration } & P. peruviana & P. pubescens & P. minima & P. ixocarpa \\
\hline & \multicolumn{4}{|c|}{ SS content } \\
\hline Full sun & $8.00 \mathrm{Bb}$ & $6.67 \mathrm{Bb}$ & $10.11 \mathrm{Aa}$ & $7.01 \mathrm{Ab}$ \\
\hline White & $9.33 \mathrm{Aa}$ & $8.33 \mathrm{Ba}$ & $10.95 \mathrm{Aa}$ & $4.67 \mathrm{Ab}$ \\
\hline Blue & $11.00 \mathrm{Aa}$ & $10.00 \mathrm{Aa}$ & $10.35 \mathrm{Aa}$ & $5.69 \mathrm{Ab}$ \\
\hline Red & $7.33 \mathrm{Bb}$ & $9.67 \mathrm{Aa}$ & $10.15 \mathrm{Aa}$ & $6.91 \mathrm{Ab}$ \\
\hline Black & $9.67 \mathrm{Aa}$ & $9.67 \mathrm{Aa}$ & $9.50 \mathrm{Aa}$ & $6.50 \mathrm{Ab}$ \\
\hline CV (\%) & \multicolumn{4}{|c|}{14.74} \\
\hline \multirow{2}{*}{ Net coloration } & P. peruviana & P. pubescens & P. minima & P. ixocarpa \\
\hline & \multicolumn{4}{|c|}{ Ratio (relation SS/TA) } \\
\hline Full sun & $6.15 \mathrm{Ac}$ & $5.99 \mathrm{Ac}$ & $14.61 \mathrm{Aa}$ & $9.24 \mathrm{Ab}$ \\
\hline White & $5.67 \mathrm{Ab}$ & $6.32 \mathrm{Ab}$ & $13.09 \mathrm{Aa}$ & $7.81 \mathrm{Ab}$ \\
\hline Blue & $5.20 \mathrm{Ab}$ & $6.73 \mathrm{Ab}$ & $13.02 \mathrm{Aa}$ & $7.07 \mathrm{Ab}$ \\
\hline Red & $5.74 \mathrm{Ac}$ & $5.84 \mathrm{Ac}$ & 11.77 Aa & $9.10 \mathrm{Ab}$ \\
\hline Black & $5.12 \mathrm{Ab}$ & $7.63 \mathrm{Aa}$ & $8.99 \mathrm{Ba}$ & $9.52 \mathrm{Aa}$ \\
\hline CV (\%) & & & & \\
\hline \multirow{2}{*}{ Net coloration } & P. peruviana & P. pubescens & P. minima & P. ixocarpa \\
\hline & \multicolumn{4}{|c|}{ Monomeric anthocyanins content (mg pelar-3-gluc-100 g $\mathrm{g}^{-1}$ ) } \\
\hline Full sun & $1.00 \mathrm{Ab}$ & $1.25 \mathrm{Ab}$ & $1.00 \mathrm{Ab}$ & $7.60 \mathrm{Aa}$ \\
\hline White & $1.00 \mathrm{Ab}$ & $1.00 \mathrm{Ab}$ & $1.00 \mathrm{Ab}$ & $2.96 \mathrm{Ba}$ \\
\hline Blue & $1.00 \mathrm{Ab}$ & $1.00 \mathrm{Ab}$ & $1.82 \mathrm{Ab}$ & $4.83 \mathrm{Ba}$ \\
\hline Red & $1.00 \mathrm{Ab}$ & $1.76 \mathrm{Ab}$ & $1.00 \mathrm{Ab}$ & $6.64 \mathrm{Aa}$ \\
\hline Black & $1.00 \mathrm{Ab}$ & $1.00 \mathrm{Ab}$ & $1.00 \mathrm{Ab}$ & $3.91 \mathrm{Ba}$ \\
\hline CV (\%) & \multicolumn{4}{|c|}{41.47} \\
\hline \multirow{2}{*}{ Net coloration } & P. peruviana & P. pubescens & P. minima & P. ixocarpa \\
\hline & \multicolumn{4}{|c|}{ Antioxidant activity (DPPH, \%) } \\
\hline Full sun & $8.96 \mathrm{Aa}$ & $3.36 \mathrm{Bb}$ & $5.32 \mathrm{Ab}$ & $5.92 \mathrm{Ab}$ \\
\hline White & $5.47 \mathrm{Ba}$ & $5.37 \mathrm{Aa}$ & $5.00 \mathrm{Aa}$ & $5.91 \mathrm{Aa}$ \\
\hline Blue & $2.55 \mathrm{Bb}$ & $2.97 \mathrm{Bb}$ & $4.90 \mathrm{Aa}$ & $5.09 \mathrm{Aa}$ \\
\hline Red & $4.32 \mathrm{Ba}$ & $5.94 \mathrm{Aa}$ & $5.69 \mathrm{Aa}$ & $3.61 \mathrm{Ba}$ \\
\hline Black & $5.44 \mathrm{Ba}$ & $5.41 \mathrm{Ab}$ & $3.19 \mathrm{Ab}$ & $3.09 \mathrm{Bb}$ \\
\hline CV (\%) & \multicolumn{4}{|c|}{29.89} \\
\hline
\end{tabular}

Averages followed by the same lowercase letter in the line and capital letter in the column are not different from one another by the Scott-Knott test at a $5 \%$ probability. $\mathrm{SS}=$ Soluble solids; $\mathrm{CV}=$ Coefficient of variation; $\mathrm{TA}=$ Titratable acidity.

coloration in fruits. Red nets broaden this relation because of their capacity to transfer spectrum light in red and far-red wavelengths, resulting in higher anthocyanin content in fruits.

Similar results were found by Amarante et al. (2007) in 'Royal Gala' apples: the radiation reduction in red and far-red wavelengths through the usage of the anti-hail black net reduced the red coloration of the fruits, a situation in which the authors draw attention to the importance of the effects of radiation quantity and quality on the coloration of fruits.

The higher anthocyanin content in P. ixocarpa in relation to other species occurs due to the fact that it is the only species which presents purple coloration. The values found for anthocyanins in P. ixocarpa were similar to the ones found by González-Mendoza et al. (2010), with approximate variation between 4 and $9 \mathrm{mg}$ pelar-3-gluc $\cdot 100 \mathrm{~g}^{-1}$. 
In the other species, the predominant pigments are the carotenoids (Lima et al. 2013), responsible for the orange coloration of the fruits. In spite of the difference in coloration, both carotenoids and anthocyanins are related to the antioxidant capacity of vegetables, thus there might be an inverse correlation of these regarding their presence in fruits.

$P$. pubescens cultivated in white and red net, $P$. peruviana in full sun, $P$. minima in white, blue and red net, as well as $P$. ixocarpa in white and blue net, were the treatments which presented higher percentage of DPPH radical kidnapping (higher antioxidant activity).

The values of antioxidant activity in P. peruviana were superior to the ones found by Licodiedoff et al. (2013) in all the colorations of colored-shade nets, except for the blue net, who presents the capacity of DPPH radical kidnapping in the range of 3.67 and 3.95. Other values of antioxidant activity are cited for the species when evaluated by the method of kidnapping of the ATBS radical. Lima et al. (2012) found antioxidant activity of 1.50 and $1.45 \%$ of kidnapping of the ABTS radical.

In $P$. ixocarpa, the antioxidant capacity evaluated by the kidnapping of the DPPH radical shows variation between 16 and $90 \%$ in different analyzed genotypes (GonzálezMendoza et al. 2010, 2011). Regardless of the genotype, all results for the species were superior to the present study, where the maximum reached value was 5.92.

In this research, significant differences were verified for the factors species and color of the colored-shade nets individually, and there was no significant interaction between these regarding the content of total phenolics present in the fruits (Table 3 ).

All the species were statistically different from one another, being the $P$. pubescens the one which presented the best performance (Table 3 ). The phenolic compounds contents found in fruits of $P$. peruviana were inferior to the ones reported by Lima et al. (2012), who found variations between 150.04 and $210.04 \mathrm{mg} \mathrm{EAG} \cdot 100 \mathrm{~g}^{-1}$; however, these values were superior to the ones of Rockenbach et al. (2008), between 57.9 and $47.8 \mathrm{mg} \mathrm{EAG} \cdot 100 \mathrm{~g}^{-1}$ of total phenolics in methanolic and aqueous extracts, respectively.
The total phenolic content of $P$. ixocarpa was $78.91 \mathrm{mg}$ EAG $100 \mathrm{~g}^{-1}$, a very different result from González-Mendoza et al. (2010, 2011), who reported values between 4.68 and 9.65 $\mathrm{mg} \mathrm{EAG} \cdot 100 \mathrm{~g}^{-1}$ and 5.3 and $10.08 \mathrm{mg}$ EAG $\cdot 100 \mathrm{~g}^{-1}$ in the two studies, respectively, both evaluating different tomatillo genus.

Regarding the coloration of the colored-shade nets under which the plants were cultivated, only under red nets the results of total phenolics were different, with a value statistically inferior to the others. This result shows the occurrence of stress in plants, probably caused by the quality of the incident light (Table 3).

Table 3. Total phenolics of fruits of four physalis species in subtropical area.

\begin{tabular}{|c|c|}
\hline Species & $\begin{array}{l}\text { Total phenolics } \\
\text { (mg EAG.100 g-1) }\end{array}$ \\
\hline P. peruviana & $93.57 b$ \\
\hline P. pubescens & $112.37 \mathrm{a}$ \\
\hline P. minima & $52.99 \mathrm{~d}$ \\
\hline P. ixocarpa & $78.91 \mathrm{c}$ \\
\hline CV (\%) & 20.93 \\
\hline Net colorations & $\begin{array}{l}\text { Total phenolics } \\
\text { (mg EAG-100 g-1) }\end{array}$ \\
\hline Full sun & $80.86 a$ \\
\hline White & $85.98 a$ \\
\hline Blue & $83.38 a$ \\
\hline Red & $70.23 b$ \\
\hline Black & 85.79 a \\
\hline CV (\%) & 20.93 \\
\hline
\end{tabular}

Averages followed by the same letter in the column are not different from one another by the Scott-Knott test at $5 \%$ probability. EAG = Gallic acid equivalent; $\mathrm{CV}=$ Coefficient of variation

\section{CONCLUSION}

The alterations in the light spectrum influence the quality of fruits of the physalis species in subtropical area. The species of physalis differ themselves regarding fruits quality. Fruits of Physalis peruviana and Physalis pubescens are more acid, and Physalis minima has higher vitamin C content.

\section{REFERENCES}

Amarante, C. V. T., Steffens, C. A., Mota, C. S. and Santos, H. P. (2007). Radiação, fotossíntese, rendimento e qualidade de frutos em macieiras 'Royal Gala' cobertas com telas antigranizo. Pesquisa Agropecuária Brasileira, 42,925-931. http://dx.doi.org/10.1590/S0100-204X2007000700003.
Awad, M. A., Wagenmakers, P. S. and Jager, A. (2001). Effects of light on flavonoid and chlorogenic acid levels in the skin of 'Jonagold' apples. Scientia Horticulturae, 88, 289-298. http://dx.doi.org/10.1016/ S0304-4238(00)00215-6. 
Campagnolo, M. A. and Pio, R. (2012). Phenological and yield performance of black and redberry cultivars in western Paraná State. Acta Scientiarum. Agronomy, 34, 439-444. http://dx.doi. org/10.4025/actasciagron.v34i4.15528.

Costa, R. C., Calvete, E. O., Reginatto, F. H., Cecchetti, D., Loss, J. T., Rambo, A. and Tessaro, F. (2011). Telas de sombreamento na produção de morangueiro em ambiente protegido. Horticultura Brasileira, 29, 98-102. http://dx.doi.org/10.1590/S0102-05362011000100016.

Cruz-Álvarez, O., Martínez-Damián, M. T., Rodríguez-Pérez, J. E., Colinas-León, M. T. and Moreno-Pérez, E. C. (2012). Conservación poscosecha de tomate de cáscara (Physalis ixocarpa Brot. ex Horm.) con y sin cáliz. Revista Chapingo. Serie Horticultura, 18, 333-344. http://dx.doi.org/10.5154/r.rchsh.2010.11.105.

González-Mendoza, D., Ascencio-Martinez, D., Poox, A. H., Mendez-Trujillo, V., Grimaldo-Juarez, O., Hernández, J. F. S., Diaz, L. C. and Marin, S. M. A. (2011). Phenolic compounds and physiochemical analysis of Physalis ixocarpa genotypes. Scientific Research and Essays, 6, 3808-3814. http://dx.doi. org/10.5897/SRE11.370.

González-Mendoza, D., Grimaldo-Juárez, O., Soto-Ortiz, O., Escoboza-Garcia, F. and Hernández, J. F. S. (2010). Evaluation of total phenolics, anthocyanins and antioxidant capacity in purple tomatillo (Physalis ixocarpa) genotypes. African Journal of Biotechnology, 9, 5173-5176. http://dx.doi.org/10.5897/ AJB10.144.

Guedes, M. N. S., Abreu, C. M. P., Maro, L. A. C., Pio, R., Abreu, J. R. and Oliveira, J. O. (2013). Chemical characterization and mineral levels in the fruits of blackberry cultivars grown in a tropical climate at an elevation. Acta Scientiarum. Agronomy, 35, 191-196. http:// dx.doi.org/10.4025/actasciagron.v35i2.16630.

Licodiedoff, S., Koslowski, L. A. D. and Ribani, R. H. (2013). Flavonols and antioxidant activity of Physalis peruviana $\mathrm{L}$. fruit at two maturity stages. Acta Scientiarum. Technology, 35, 393-399. http://dx.doi. org/10.4025/actascitechnol.v35i2.13265.

Lima, C. S. M., Galarça, S. P., Betemps, D. L., Rufato, A. R. and Rufato, L. (2012). Avaliação física, química e fitoquímica de frutos de Physalis, ao longo do período de colheita. Revista Brasileira de Fruticultura, 34, 1004-1012. http://dx.doi.org/10.1590/ S0100-29452012000400006.
Lima, C. S. M., Severo, J., Andrade, S. B., Affonso, L. B., Rombaldi, C. V. and Rufato, A. R. (2013). Qualidade pós-colheita de Physalis sob temperatura ambiente e refrigeração. Revista Ceres, 60, 311317. http://dx.doi.org/10.1590/S0034-737X2013000300002.

Maro, L. A. C., Pio, R., Santos, G. M. N., Abreu, C. M. P. and Curi, P. N. (2013). Bioactive compounds, antioxidant activity and mineral composition of fruits of raspberry cultivars grown in subtropical areas in Brazil. Fruits, 68, 209-217. http://dx.doi.org/10.1051/ fruits/2013068.

Patel, P. R., Gol, N. B. and Rao, T. V. R. (2011). Physiochemical changes in sunberry (Physalis minima L.) fruit during growth and ripening. Fruits, 66, 37-46. http://dx.doi.org/10.1051/fruits/2010039.

Puente, L. A., Pinto-Muñoz, C. A., Castro, E. S. and Cortés, M. (2011). Physalis peruviana Linnaeus, the multiple properties of a highly functional fruit: a review. Food Research International, 44, 17331740. http://dx.doi.org/10.1016/j.foodres.2010.09.034.

Ramírez-Godina, F., Robledo-Torres, V., Foroughbakhch-Pournabav, R., Benavides-Mendoza, A., Hernández-Piñero, J. L., Reyes-Valdes, M. H. and Alvarado-Vázquez, M. A. (2013). Yield and fruit quality evaluation in husk tomato autotetraploids (Physalis ixocarpa) and diploids. Australian Journal of Crop Science, 7, 933-940.

Rockenbach, I. I., Rodrigues, E., Cataneo, C., Gonzaga, L. V., Lima, A., Mancini Filho, J. and Fett, R. (2008). Ácidos fenólicos e atividade antioxidante em frutos de Physalis peruviana L. Alimentos e Nutrição, 19, 271-276.

Senhor, R. F., Souza, P. A., Carvalho, J. N., Silval, F. L., Silva, M. C. (2009). Fatores pré e pós-colheita que afetam os frutos e hortaliças em pós-colheita. Revista Verde de Agroecologia e Desenvolvimento Sustentável, 4, 13-21.

Silva, D. F., Villa, F., Barp, F. K., Rotili, M. C. C. and Stumm, D. R. (2013). Conservação pós-colheita de fisális e desempenho produtivo em condições edafoclimáticas de Minas Gerais. Revista Ceres, 60, 826-832. http://dx.doi.org/10.1590/S0034-737X2013000600011.

Souza, V. R., Pereira, P. A. P., Silva, T. L. T., Lima, L. C. O., Pio, R. and Queiroz, F. (2014). Determination of the bioactive compounds, antioxidant activity and chemical composition of Brazilian blackberry, red raspberry, strawberry, blueberry and sweet cherry fruits. Food Chemistry, 156, 362-368. http://dx.doi.org/10.1016/ j.foodchem.2014.01.125. 